ЛЮДМИЛА СТРУТИНСЬКА-СТРУК

(LUDMILA STRUTYNSKA-STRUK)

Чернівецький національний університет

ім. Юрія Федьковича, Україна

(Yurii Fedkovych Chernivtsi National University, Ukraine)

\title{
Міжнародно-правові засади польсько-українського співробітництва: проблеми та можливі перспективи
}

\section{International and Legal Principles of Polish-Ukrainian Cooperation: Problems and Possible Perspectives}

The author summarises the process of creating the necessary contractual and legal framework aimed at the development of multilevel relations between the Republic of Poland and Ukraine in accordance with the requirements of international law, as well as national and European legislation.

Keywords: international law, Polish-Ukrainian cooperation, independence.

Із здобуттям Україною незалежності, а Польщею - реальної свободи дій, постали об' єктивні умови, які вимагали формування між державами взаємин якісно нового типу. Їх розвиток у значній мірі залежав від подальших зовнішньополітичних намірів Польщі та України, як глобального, так і регіонального вимірів. Безумовно, становлення всебічних, багаторівневих відносин між Республікою Польща та Україною було неможливим без створення необхідної договірно-правової бази, що відповідала б вимогам міжнародного права, національного та європейського законодавств. Це було обов'язковою підставою, яка б гарантувала позитивну динаміку процесу, що розпочинався.

Варто наголосити, що Сейм Республіки Польща 31 серпня схвально сприйняв Акт Незалежності України, проголошений у Києві Верховною Радою 24 серпня 1991 p. ${ }^{1}$ Власне саме Республіка Польща вже на другий

1 Uchwata Sejmu Rzeczypospolitej Polskiej z dnia 31 sierpnia 1991 r. w sprawie niepodległości Ukrainy, Monitor Polski 1991 Nr 29, poz. 205. 
день після референдуму 2 грудня 1991 р. визнала незалежність України. Про це офіційно повідомив МЗС України спеціальний посланник польського уряду у Києві Єжи Козакевич. У свою чергу, польський парламент на засіданні 6 грудня засвідчив, що повстання незалежної української держави є доленосною подією не тільки для України, але також і для Свропи, відкриває нову епоху у польсько-українських стосунках ${ }^{2}$.

Договірна база між Україною та Польщею на сьогодні налічує понад 160 документів більшої чи меншої ваги ${ }^{3}$. Серед джерел слід відзначити документи, які заклали підвалини співробітництва між Україною і Польщею - «Декларація про принципи і основні напрямки розвитку українсько-польських відносин» від 13 жовтня 1990 року»4, «Договір між Україною і Республікою Польщею про добросусідство, дружні відносини і співробітництво» від 18 травня 1992 року ${ }^{5}$, Основні напрямки зовнішньої політики України» від 2 липня 1993 року ${ }^{6}$. У них містяться базові положення про співпрацю двох держав у сфері політики, економіки, міжнародних відносин, культури.

Саме ці базові угоди та договори створили можливість для розробки і підписання відповідних документів вже на регіональному рівні, а також між польськими містами, воєводствами, повітами, гмінами та українськими містами, областями, районами. У цей же час відкриваються консульські інституції - генеральні консульства України у Гданську (22 серпня 1994 р.) і Кракові (15 серпня 1997 р.) та консульства РП у Львові й Харкові, а пізніше в Луцьку, Одесі та Вінниці. Приєднання обох держав у 1994 р. до Програми «Партнерство заради миру» також стимулювало поглиблення різнопланових контактів між Україною та Польщею.

Проведений аналіз проблеми, винесеної в назву нашого наукового дослідження, дає підстави констатувати, що постала відповідна національна та міжнародно-правова база, яка сприяє формуванню сприятливих юридичних умов для активізації роботи по підготовці двосторонніх

2 Uchwała Sejmu Rzeczypospolitej Polskiej z dnia 6 grudnia 1991 r. w sprawie niepodległości Ukrainy, Monitor Polski $1991 \mathrm{Nr} 45$, poz. 316.

3 Ukraina-Po'lshcha: mizhderzhavni dokumenty, http://poland.mfa.gov.ua/ua/ukraine-pl/ legal-acts (dostup: 18.07.2017).

4 Deklaraciâ o principah i osnovnyh napravleniâx razvitiâ ukrainsko-pol'skih otnošenij, „Pravda Ukrainy”, 17 IX 1990, c. 3.

5 Dogovir pro dobrosusidstvo, druzhni vidnosyny i spivrobitnyctvo, „Polityka i chas” 1992, № 7-8, c. 9-14.

6 Pro „Ocnovni napriamky zovnishn'oi polityky Ukrainy, zatverdzheni Verhovnoju Radoju Ukrainy vid 2 lypnia 1993 r.”, „Golos Uklriny”, 24 VII 1993, № 111. 
польсько-українських документів у сфері торговельно-економічного та енергетичного співробітництва, прикордонної співпраці, транспорту, екології, культурно-гуманітарного співробітництва, молодіжної політики та військово-технічної співпраці тощо. Про важливість договірно-правової бази на рівні двосторонніх домовленостей між суб'єктами адміністративно-територіального устрою України та Республіки Польща свідчить і статистика. На даний час їх кількість вже наближається до 500.

Важливим кроком у розвитку законодавчої бази стало прийняття 14 липня 1993 р. Верховною Радою України Постанови про приєднання України до Європейської рамкової конвенції про транскордонне співробітництво $^{7}$, а також Закону України від 24 червня 2004 р. «Про транскордонне співробітництво» $^{8}$. Це, у певній мірі, сприяло створенню єврорегіонів, в яких були задіяні Польща та Україна, зокрема «Буг» та «Карпатський». Власне Карпатський Сврорегіон (Сврорегіон «Карпати») став першою міжрегіональною асоціацією на території постсоціалістичного простору. Наразі Карпатський Єврорегіон є одним із найбільших на Європейському субконтиненті: його площа - 154 тис. км², кількість населення перевищує 16 млн. осіб. Сврорегіон «Карпати» входить до Асоціації європейських прикордонних регіонів 9 .

Закладені юридичні основи дали можливість заснування Міжнародних польсько-українських комісій різного спрямування. Так, наприклад, на підставі спільної Угоди про економічну співпрацю, яка була прийнята урядом РП та Кабінетом міністрів України 4 березня 2005 р. була створена Міжнародна польсько-українська комісія з економічної співпраці, почали проводитись спільні бізнес-форуми, як у Польщі, так і в Україні. Постійно, хоча не так швидко, як хотілось би, зростає товарообіг між двома країнами. Україна займає 15 місце серед головних імпортерів польських товарів.

Висновки та можливі перспективи. Радикальне реформування в Україні місцевого самоврядування, яке передбачає його децентралізацію, вимагає від законодавців розробки і прийняття відповідних законів та угод, які сприяли б подальшій активізації міжрегіонального

7 Postanova VR Ukriny „Pro przjednia Ukrainy do Europej skoi ramkovoi konvencii pro transkordonne spivrobitnycrvo mizh terytoria'lnymy obshchynamy abo vla'sciamy", VVRU 1993, № 36.

8 Zakon Ukrainy „Pro transkordonne spivrobitnyctvo vid 24.06.2004”, VVRU 2004, № 45, http://zakon2.rada.gov.ua/laws/show/1861-15 (dostup: 18.07.2017).

9 Karpats'kyj euroregion (Ukraina, Pol'shcha, Slovachchyna, Rumunia), www.bukoda. gov.ua/page/karpatskii-evroregion (dostup: 18.07.2017). 
та транскордонного співробітництва як основної складової регіональної політики нашої країни. При цьому повинно бути враховано європейське законодавство 3 даного питання й використано досвід реформування місцевого самоврядування нашого провідного стратегічного партнера - Польщі.

Також необхідно спільними зусиллями двох країн, окрім збільшення кількості пунктів перетину кордону, розробити та впровадити в життя дієві нормативно-правові заходи, які різко спростили б процедуру перетину польсько-українського кордону. На сьогодні, з впровадженням біометричних паспортів, це стає однією з найбільш складних проблем як для юридичних, так і для фізичних осіб. Фактично позитив від впровадження безвізового режиму нищиться багатогодинним стоянням на кордоні.

При розробці законодавцями двох країн внутрішньодержавних законів, підзаконних актів, особливо в галузі освіти, культури, науки, які мають у чомусь і політичне забарвлення, треба враховувати наявність гострих питань у спільній історії Польщі та України. Ними повинні займатись історики, а не недалекоглядні політики, що використовують їх у своїх цілях. У кінцевому підсумку це шкодить двом сусіднім народам і використовується ворогами нашої єдності, як у середині країн, так і зовні.

\section{Bìblìografîa}

Deklaracija o princypah I osnovnyh napravlenijah razvitija ukrainsko-pol'skih otnoshenij, „Pravda Ukrainy”, 17 IX 1990.

Dogovir pro dobrosusidstvo, druzhni vidnosyny I spivrobitnyctvo, „Polityka i chas” 1992, № 7-8. Karpats'kyj euroregion (Ukraina, Pol'shcha, Slovachchyna, Rumunia), www.bukoda.gov.ua/ page/karpatskii-evroregion.

Postanova VR Ukriny „Pro przjednia Ukrainy do Europej skoi ramkovoi konvencii pro transkordonne spivrobitnycrvo mizh terytoria 'lnymy obshchynamy abo vla'sciamy", VVRU 1993, № 36.

Pro „Ocnovni napriamky zovnishn'oi polityky Ukrainy, zatverdzheni Verhovnoju Radoju Ukrainy vid 2 lypnia $1993 r$.”, ,Golos Uklriny”, 24 VII 1993, № 111.

Uchwała Sejmu Rzeczypospolitej Polskiej z dnia 31 sierpnia 1991 r. w sprawie niepodlegtości Ukrainy, Monitor Polski 1991 Nr 29, poz. 205.

Uchwała Sejmu Rzeczypospolitej Polskiej z dnia 6 grudnia 1991 r. w sprawie niepodlegtości Ukrainy, Monitor Polski $1991 \mathrm{Nr}$ 45, poz. 316.

Ukraina-Pol'shcha: mizhderzhavni dokumenty, http://poland.mfa.gov.ua/ua/ukraine-pl/legal-acts. Zakon Ukrainy ,Pro transkordonne spivrobitnyctvo vid 24.06.2004”, VVRU 2004, № 45, http://zakon2.rada.gov.ua/laws/show/1861-15. 